\title{
Gender bias in the media: the case of Iceland
}

\author{
Valgerður Jóhannsdóttir, Adjunct Lecturer in Journalism, University of \\ Iceland
}

Porgerður Einarsdóttir, Professor in Gender Studies, University of Iceland

\begin{abstract}
The news media are the most influential sources of information, ideas and opinion for most people around the world. Who appears in the news and who is left out, what is covered and what is not and how people and events are portrayed matter. Research has consistently shown that women are underrepresented in the news and that gender stereotypes are reinforced in and through the media. The 1995 Beijing Declaration and Platform for Action recognised the relationship between women and media as a major area of concern in achieving gender equality in contemporary societies. This article presents Nordic findings from the 2015 Global Media Monitoring Project (GMMP), which is the largest and longest-running study on gender in the world's media. The findings show that women account for only 1 in 5 of the people interviewed or reported on by Icelandic news media and that women's overall presence in the news has declined compared to the last GMMP study in 2010. The proportion of women as news subjects is also considerably lower than in other Nordic countries. We argue that the number of women who are journalists, managers in the media industry and decision makers in society has increased, but this shift has not automatically changed the representation of women in the news, either in numbers or in their portrayal. This discrepancy indicates that the relationship between gender and the news media is complicated and needs to be approached from different perspectives.
\end{abstract}

Keywords: Gender and media; portrayal of men and women: news; journalism.

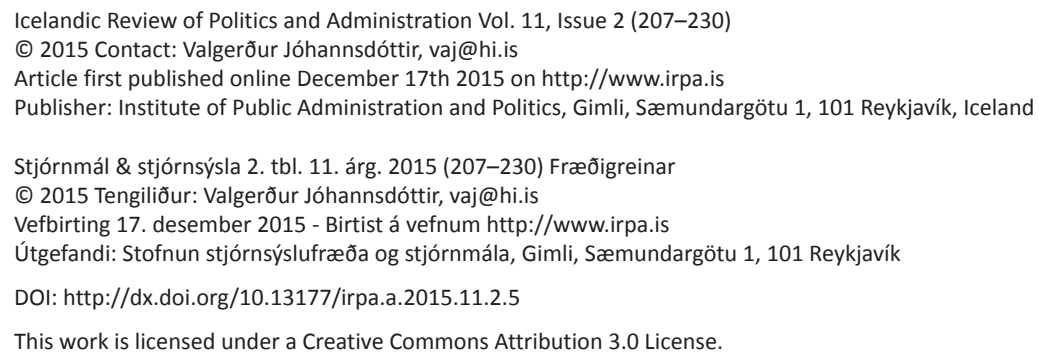




\section{STJÓRNSÝSLA}

\section{Introduction}

The Beijing Declaration and Platform for Action produced at the 1995 United Nations Fourth World Conference on Women recognises the relationship between women and media as a major area of concern in achieving gender equality in contemporary societies. The action platform stresses the importance of increasing women's participation in and access to expression and decision making in and through the media and promoting a balanced, non-stereotyped portrayal of women in the media (World Conference on Women 1995). UNESCO's Priority Gender Equality Action Plan 2008-2013 also emphasises the role of the media in gender equality. In 2009, UNESCO, in partnership with the International Federation of Journalists (IFJ), published the handbook Getting the Balance Right. In the preface, the IFJ chairperson Aidan White, writes that fair gender portrayals are:

a professional and ethical aspiration, similar to respect for accuracy, fairness and honesty. ... In a world where hard news is still mainly reported and presented by men journalists need to stand up for gender equality. This equality is not just a women's issue; everyone benefits from eliminating discrimination (White 2009, V).

White (2009, V) posits that getting the gender balance right and resisting the culture of casual stereotypes is one of journalists' greatest challenge and argues that journalism has 'its roots in the fight for decency, progress and rights for all' and needs to honour this tradition. However, journalists alone cannot be held responsible for getting the balance right in the news media. One of the most important contributions the Beijing Platform for Action made to advancing gender equality in and through the media was setting global standards to hold governments and the media accountable. Both the European Union (EU) and the European Council have recently started to put more pressure on member states to take actions to increase gender equality in the media, both within media organisations and in their output. EU member states, for example, are required to deliver annual reports on their progress fulfilling the Beijing Action Plan objectives (Edström 2015).

Among the objectives of the action plan are supporting women's education, training and employment to promote and ensure equal access to all areas and levels of the media and to support research on all aspects of women and media (World Conference on Women 1995). Icelandic media companies are obliged to work for gender equality under the Act on the Equal Status and Equal Rights of Women and Men (Law no. 10/2008). They also report to the Media Commission, an independent administrative committee, on issues concerning the representation of women and men, such as the proportion of men and women interviewed in news and current-affairs programming, gender portrayals in the content produced and the number of women and men employed and their positions (Law no. 38, 2011). 


\section{STJÓRNMÁL

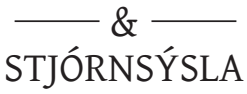

At the 1995 conference in Beijing, the findings of the Global Media Monitoring Project (GMMP), the first global study of the representation and portrayal of women and men in the world's news media, were presented. The findings were based on monitoring of news media in 71 countries for one day (GMMP 2005). Every five years since 1995, the GMMP has mapped the representation and portrayal of women in the world's news media. It is the longest-running and most extensive research on gender in the world's media to date, and 114 countries took part in the most recent study in 2015 (GMMP 2015). Iceland participated in the GMMP in 1995, 2000, 2010 and again in 2015. Participation in the GMMP enables the first study of gender in the Icelandic news media in a global context and the following of changes over time.

Gender-equal representation in decision making in the media industry and in the representation and portrayal of women in the media are both legitimate, worthwhile objectives. It is often assumed that there is a relationship between the two, that a higher number of women at decision-making levels in organisations will increase gender equality at lower levels. For example, it has been maintained that a higher number of women in decision-making positions in the media will improve the representation of women and lead to less stereotyped portrayals of women in the media (EIGE 2013). This correlation has also been an implicit assumption in economic life and business, but it has not been proved to be certain: a higher number of women in decision-making positions in companies does not automatically lead to more gender-equal organisations (Bertrand et al. 2014; Kitterød et al. 2015).

'How many times have we heard the excuse that media are just a reflection of what is happening in reality?' (Hermano \& del Nevo 2000, 7). The 20 years since the first GMMP study have seen a steady increase in the number of female journalists (Hanitzch 2014) and a relative rise in women's prominence in decision-making positions, political office, company boards and other positions of influence (Statistics Iceland 2015; Rafnsdóttir, Einarsdóttir \& Snorrason 2014) but a much slower and more uncertain increase in the proportion of women as news subjects (GMMP 2010). It is often claimed that mass media reflect but not create reality, an assumption which has been challenged (Tuchman 1979).

To address these questions, we draw upon data from the GMMP project, particularly the 2015 GMMP, and compare Iceland to other Nordic countries and to the background of women working in the media environment. We argue that the number of women who are journalists, managers in the media industry and decision makers in society has increased, but the same has not happened in the representation and portrayal of women in the media. This discrepancy indicates that there is not a simple relationship between women's numerical and content representation in the media, on one hand, and their representation in the media industry and decision-making positions in society, on the other hand. Therefore, we argue that this issue needs to be approached from a broad perspective. 


\section{Women and men in the media}

Research has consistently shown that women are underrepresented in the news (e.g. Tuchman et al. 1978; Van Zoonen 1998; Ross \& Carter 2011; Baitinger 2015; Shor et al. 2013; Andreassen 2015). Eide $(2001,7)$ argued that once women comprise $20 \%-25 \%$ of news interviewees or subjects, an upper limit, or 'pain threshold', is reached in the news media. The findings of the first GMMP study in 1995 showed that women accounted for only $17 \%$ of those interviewed in the world's news. In 2000 , the proportion of women among news subjects or sources was 18\%; it rose to $21 \%$ in 2005 and $24 \%$ in 2010 (GMMP 2010). A recent study (Shor et al. 2013) of the coverage of female subjects in 13 daily newspapers in the United States from 1880 to 2008 reveals that representation of female subjects has remained relatively low, less than $25 \%$ overall. Although there has been some improvement since the late 1960s, it is not in line with the progress in gender equality made in various social and public spheres over the past 50 years, and no newspaper section even comes close to equality between males and females. The authors ponder whether newspaper coverage of female subjects has reached a 'paper ceiling' (Shor et al. 2013, 767).

The Nordic countries rank high on most, if not, all international measurements of gender equality (World Economic Forum 2015), and there is a political consensus in these countries that women and men should enjoy the same rights, obligations and possibilities in society. However, male dominance persists in the Nordic news media, and the proportion of women among news subjects has remained stable around $30 \%$ for years (Edström \& Mølster 2014; Byerly 2011), slightly higher than Eide's (2001) pain threshold. Although the Global Gender Gap Index can be seen as a narrow instrument which leaves out important aspects (gender based violence, gender in media) but records unnecessary details about others, it still gives an indication of long-term trends from an international perspective. Iceland has topped the overall rankings of the Global Gender Gap Index for the seventh consecutive year (WEF 2015). If mass media only reflected and did not create reality, the representation of women in Icelandic could be expected to be high, which is not the case, as discussed later.

In Iceland, as elsewhere, most of the research on gender and media has focused on the representation of women and men in media content (Andreassen 2015). Icelandic research, though, is scarce and somewhat fragmented. According to the first study on gender representation in Icelandic media (Stefánsdóttir 1988), no women were interviewed during the first five years of Icelandic television news. Women slowly started to appear in the news during the 1970s, and in 1986, women accounted for 13\% of those interviewed in the television news. By 2000, the situation had improved, but women were still grossly underrepresented in all kinds of media content, at $32 \%$ overall and $27 \%$ of those interviewed in television news, according to a report commissioned by the Ministry of Education and Culture (Nefnd um konur og fjölmiðla 2001).

The findings of another report commissioned by the ministry in 2005 showed that little had changed (Valdimarsdóttir 2005). Women constituted around 1 in 5 of those interviewed for television news on the private Channel 2 and 1 in 4 on RÚV, a public 


\section{STJÓRNMÁL \& \\ STJÓRNSÝSLA}

broadcasting company. The 2010 GMMP study revealed that women accounted for $28 \%$ of all news subjects in Iceland, higher than the overall average of $24 \%$ in the study and the regional European average of 26\% (Árnadóttir et al. 2010). Iceland trailed a little behind other Nordic countries in this area in 2010: women made up 30\% of news subjects in television, radio and newspapers in Denmark, 32\%in Finland and Sweden and 33\% in Norway (GMMP 2010; see also Edström 2015; Andreassen 2015; Øvrebø 2015; Savolainen \& Zilliacus-Tikkanen 2015). According to a 2013 study of the main newscast on Channel 2 and RÚV, women accounted for approximately $30 \%$ of interviewees, with no real difference between the two channels (Jóhannsdóttir \& Karlsson 2013).

The familiar 30/70 ratio was also found in a report by Creditinfo, a media watch company, produced for the Association of Business Women in Iceland (2013). The report looked at women and men interviewed in broadcast news and current affairs programmes from February 2009 to August 2013. Of the more than 100,000 people interviewed over this period, $30 \%$ were women, and they were more likely to appear in current affair programmes than in the news. During this period, their share of representation grew from $30 \%$ to $35 \%$ in current affair programmes, but in the news, their share was lower and increased at a slower pace, from 26\% to 28\% (Association of Women Business Leaders in Iceland 2013). Creditinfo repeated this study for the Ministry of Welfare in connection with the annual Equal Rights Conference 2015 (Erlingsdóttir 2015). The findings show that women made up $32 \%$ and $30 \%$ of those interviewed in current affair programmes and in the main newscasts, respectively, from September 2014 through September 2015. The proportion of women interviewees was considerably higher in current affair programmes on the public broadcaster RÚV than in the privately owned 365 Media $(37 \%$ vs. $27 \%$ ). In newscasts, there was less difference among the types of media. In radio, women constituted $23 \%$ of interviewees in the morning news and $27 \%$ in the noon news on 365 Media and 26\% in the morning news, $27 \%$ in the noon news and $30 \%$ in the evening news on RÚV. In television news, there was little difference between the public and the private media. In the main evening news, women accounted for approximately $30 \%$ of interviewees over the one-year period (Erlingsdóttir 2015).

Not only are fewer women than men heard, seen or written about in the media, but women also often appear in different roles and are portrayed differently. According to the 2005 report commissioned by the Ministry of Education and Culture, the portrayals of women and men are extremely unbalanced in all media content in entertainment, news, current affairs programmes, talk shows and advertising message (Leiknisdóttir 2005; Jakobsdóttir 2005). In advertising and current affairs programmes, women were younger than men and most often models, whereas men presented the message. In the news, no women were portrayed in local and international politics, industry, fishing or science coverage, and women appeared more frequently than men only in coverage of social issues (Valdimarsdóttir 2005). A study on European media coverage of women and men in sports showed that stories about women athletes more commonly were degrading or have sexual undertones and that sports coverage reinforced traditional gender stereotyping (Ólafsson 2006). 
News stories about women in politics often focus on their sex and comment on their appearance and clothing (Einarsdóttir \& Hjartardóttir 2009). Women are less visible in stories on such topics as politics, the economy and crime than health and social care, education, consumer issues and other topics traditionally regarded as of special interest to women (Ross \& Carter 2011; GMMP 2010). For example, women accounted for only $3 \%$ of those interviewed in the Icelandic news media coverage of financial companies from January 2006 until the financial crash in October 2008 (Guðmundsson et al. 2010). According to a study on the 2009 national election campaign in Iceland, newspaper coverage did not reflect the ratio of women and men who were candidates (Pórisdóttir 2010). The ratio of female candidates was much higher than the coverage indicated. Andreassen (2015) notes that women served as only $28 \%$ of the sources in political news in Denmark, even though the leaders of half the political parties and more than $40 \%$ of ministers and $37 \%$ of members of parliament were women. The results from Iceland in the 2010 GMMP study were inconclusive in this respect (Árnadóttir et al. 2010). Women made up 15\%-38\% of the news subjects or sources depending on the topic: $38 \%$ of politicians interviewed, spoken of or written about were women, while $62 \%$ were men. In economy and business, women accounted $10 \%$ of the sources, and men 90\% (Árnadóttir et al. 2010). The 2010 GMMP also shows that numbers only tell half the story as the portrayal of women comes across as gendered: compared to men, women are less often mentioned by name in comparable news stories, and the portrayal of women is more often focused on their age and appearance, accompanied with sexual undertones (Árnadóttir et al. 2010).

Women are also less likely to appear in the news as experts or commentators than men. In Pórisdóttir's (2010) study of election coverage in Icelandic newspapers, almost all experts and commentators interviewed were men (97\%). The author points out that this discrepancy cannot be explained by a lack of female experts in the field as women comprise almost two thirds of those who have graduated with a master's degree in political science (Dórisdóttir 2010). Studies have supported cultural gendered notions in which men are seen as embodying a (universal) truth, while women are seen as embodying a more subjective knowledge (Øvrebø 2013). In a more recent study of news production in the television news and current affairs programme Dagsrevyen, Øvrebø $(2015,45)$ found that men were portrayed as elites, politicians, experts and bearers of knowledge and (objective) truth, whereas women sources more frequently appeared as 'ordinary people' and sources for their own (subjective) experience. In a study of the newspaper Dagsavisien, Øvrebø (2015) noted that men were perceived as bringing authority and truth to the news and adding weight to the newspaper, which was considered important in the competitive news industry (Øvrebø 2015). Ross and Carter (2011) found that the same pattern occurred to British media as women were invited to provide personal testimony and impressionistic anecdotes rather than authoritative, informed perspectives (Ross \& Carter 2011). These findings are in line with Allan's (1988/2014) arguments on the gendered news discourse in the British media. 


\section{STJÓRNMÁL \& \\ STJÓRNSÝSLA}

\begin{abstract}
'Masculine' discourses about reality (held to be objective, rational, abstract, coherent, unitary and active) are discursively privileged over 'feminine' ones (posited as subjective, irrational, emotional, partial, fragmented and passive). Implied in this dynamic is the perceptive that 'feminine knowledge' is being understood as being inferior to 'masculine truth'. (Allan 1988/2014, 126)
\end{abstract}

\title{
2. Women and men in journalism
}

The number of women in journalism has grown remarkably around the world in recent decades (Hanitzsch \& Hanusch 2012). According to a survey of European journalists, the average proportion of female and male journalists (47\% vs. $53 \%$ ) is almost equal across the continent (Whitt-Barthel 2006). In Finland, women made up $40 \%$ of the members of the journalist's union as early as 1978, and by the 1990s, half were women, now constituting a majority of Finnish journalists (57\%) (Savolainen \& Zilliacus-Tikkanen 2015). Women began entering the journalism profession in Sweden in force during the 1970 s, reached parity with men in the 1990 s and now are $51 \%$ of the members of the journalists' union. Women make up $43 \%$ and $44 \%$ of the members of the journalists' union in Norway and Denmark, respectively (Edström \& Mølster 2014).

Women journalists were rare in Icelandic media until the late $20^{\text {th }}$ century. A 1962 article in a popular weekly magazine noted that the journalism profession had clearly become popular among women, and as proof, the article contained short interviews with all eight women working as journalists in Iceland at the time (Blaðakonur á Ísland 1962). Their numbers grew, albeit slowly, and twenty years later, a quarter-in total 64 of all members of the two journalists' unions were women. In 2014, the proportion of women working in media had reached $43 \%$, although the size of the media workforce had declined considerably over the past decade (Statistics Iceland 2015). A possible explanation of why women entered journalism later in Iceland than other Nordic countries is that journalism education was started later in Iceland, and it was degrees in journalism that paved the way for women to enter the profession in many countries (Guðmundsson 2009a). For some years, women have outnumbered men in journalism education in Iceland, as well as the other Nordic countries. Today, 2 out of 3 journalism students are women in Iceland, Finland, Norway, Sweden and Denmark (Hovden et al. 2009; Guðmundsson \& Jóhannsdóttir 2013; Stefánsdóttir 2013).

The proportion of women in journalists' unions or associations does not entirely reflect the proportion of female journalists in news media. Women often work in other types of media, such as periodicals, magazines and publishing houses (Savolainen \& Zilliacus-Tikkanen 2015). In a 2012 survey of journalists in the Icelandic news media (excluding magazines) women accounted for 35\% of the workforce and men 65\% (Kolbeins 2012). According to the survey the average male journalist was 42 years old and with 14 years of experience working in the media, but his female counterpart was 6 years younger and had worked as a journalist for eight years. Both worked on average 44 


\section{STJÓRNSÝSLA}

hours a week and although male journalists earned on average slightly more than female journalists the difference was not significant.

In the first GMMP study in 1995, the global percentage of news reported by women was 28\%, but in 2010, it had risen to 37\% (GMMP 2010). The 2010 study showed that women reported $33 \%$ of the news in Icelandic media, compared with a little more than half in Sweden, 40\% in Finland and 30\% in Norway and Denmark (Árnadóttir et al. 2010). A recent Icelandic study also shed light on the prevalence of masculine values in the media environment based on the different values assigned to the topics and the lower ranking of the news produced by female journalists compared to male journalists (Hálfdánardóttir 2014). The study indicated that women were likely to object to the dominant values and measures by which news were ranked.

In recent years, more attention has been paid to women's positions in the media industry, and studies have shown that women's climb to top positions has proved to be harder than getting into the profession. Despite increasing number of women entering the industry, 'most research suggest[s] that they get stuck at the middle management and rarely achieve the really high jobs' (Ross 2014, 37). Women are still largely underrepresented at higher levels in media organisations in Europe, according to a study of 99 media organisations in 28 EU member states (EIGE 2013). Women held $32 \%$ of all decision-making positions, but their presence decreased the higher up the hierarchy one went, and at the highest level (chief executive officer, chairperson, president, director or similar position), only $16 \%$ of managers are women. The proportion of female leaders is higher in public media organisations than in private media and higher in organisations that had gender-equality policies and measures in place (EIGE 2013). In Nordic countries, the proportion of women in high positions is generally higher (Edström \& Mølster 2014). The number of women in high-ranking editorial positions has increased in the past decade, especially in Sweden, where, for example, women accounted for $42 \%$ of editors-in-chief in the printed press in 2013. In Finland, women's share was 35\%, but it was much lower in Denmark and Norway, at 16\% and 10\%, respectively (Edström \& Mølster 2014).

In a 2011 report by the Ministry of Education and Culture, the Committee on Women and Media noted that, despite the growing number of women entering journalism, only a few made it to the top (Nefnd um konur og fjölmiðla 2001). Far more men than women occupied leadership positions, although $70 \%$ of women were interested in furthering their career in the media. A survey conducted by Statistics Iceland (2009) to determine the gender ratio at different levels of the managerial structure of Icelandic daily newspapers in 1980, 1985, 1990, 1995, 2000 and 2007 revealed that it is difficult for women to reach the position of chief editor. During the years observed, the chief editors were all male, except for several months in 1988 when a woman served as an editor at one newspaper. Starting in 1980, the newspapers' editors were all male until 2002 , after which one to two women served as editors along with four to five men. From 1980 until 2005, newspaper's news editors were all male, while from 2005 to 2007, one to two women served as editors compared to three to five men (Statistics Iceland 2009). 


\section{STJÓRNMÁL \& \\ STJÓRNSÝSLA}

In 2015, women were appointed as one of two editors of $D V$, Iceland's only tabloid newspaper, and a deputy editor of the online news site Kjarninn. The two editors, chair of the board and eight of 13 leaders in the editorial office of Morgunbladid, Iceland's oldest newspaper, are men (Jóhannsdóttir 2015).

In radio and television organisations, only men served as directors as late as 2007. From 1968 to 1986, one woman was the radio news editor at RÚV, the public broadcasting company. After that, men served as news editors both for public radio and television until 2003, when a woman was appointed as television news editor at RÚV, a position filled by a man from 2008 to 2014. In private radio and television companies, women were news editors for only three of the years observed (1990, 1995, 2004), while men were for all the other years (Statistics Iceland 2009). Recently, there has been some improvement. The male director of RÚV appointed in March 2014, has declared that gender equality will be a company priority (Olgeirsson 2014). Shortly after his appointment, changes were made in the eight-man board of executives so that there are equal numbers of men and women for the first time. As well, a woman was appointed news editor. In 2014, changes also occurred at the top level in Iceland's biggest media company, 365 Media, and the new director has said that recruiting more women journalists will be a priority (Viðskiptablaðið 2014). The new publisher of 365 Media and the head of the company's news department is a woman, as is the main owner and chairperson of the company.

It has been and still is a highly common belief, either explicitly or as an underlying assumption, among both female journalists and media researchers that more female journalists results in more gender equality in media content (Tuchman 1979; Øvrebø 2013; Steiner 2012). In the 1980s, it was argued that, once women journalists reached the critical 33\% mark, they would be able to influence the news culture and, thereby, the news content (Hanitzsch \& Hanusch 2012). The research findings on this relation, however, have been contradictory. There are some indications that the gender of journalists may affect content, especially the choice of sources and the tone and style of writing (GMMP 2010; Savolainen \& Zilliacus-Tikkanen 2015). In a 2001 survey among Icelandic journalists, $62 \%$ of the women said that their work practices, writing style, topic interests and approaches to subjects differed from men's (Nefnd um konur og fjölmiðla 2001). In a 2007 survey by the Union of Icelandic Journalists, a large majority of women $(78 \%$ ) but only $46 \%$ of men agreed with the statement that journalists should make an effort to report equally about men and women. In addition, 18\% of the women but $8 \%$ of the men said they always tried to balance the ratio of women and men they interviewed (Guðmundsson 2009b).

According to the GMMP (2010) study, a global trend over the past 10 years has been that stories reported by women journalists feature more women as news subjects $(28 \%)$ than those reported by male journalists (22\%). In the 2010 GMMP study, however, women reporters in the Icelandic news media were not more likely to have female news subjects than male reporters (Árnadóttir et al. 2010). In Scandinavian countries, women have reached near parity with men in newsrooms, but the representation of 


\section{STJÓRNSÝSLA}

women as news subjects seems to have plateaued at 30\% (Edström 2015). In Øvrebø's aforementioned study of the Norwegian media, the lowest representation of women was found in the national newspaper with the highest gender parity in the newsroom and a female editor-in-chief (Øvrebø 2013). A large-scale comparative study on gender differences in the professional orientations of journalists in 18 countries found no evidence to support claims that the professional views of women and men differed significantly (Hanitzsch \& Hanusch 2012). Based on earlier research, Shor et al. (2013) claim that the gender of a reporter has only a moderate or no effect on gendered coverage patterns. Shor et al. (2013) conclude that structural factors, such as hegemonic journalistic practices and traditional patterns of coverage, may be more important than individual factors. Consequently, the individuals who draw public attention continue to be overwhelmingly male (Shor et al. 2013).

When the proportion of women journalists reached and then surpassed the critical mass of $30 \%$ without making the expected differences, scholars started looking for other explanations for the lack of women in leadership positions (Steiner 2012). In the foreword to an EIGE report on women and media, Virginija Langbakk, director of the European Institute for Gender Equality, posits that an increased presence of women in decision-making positions in the media would 'lead to a more equal and gender sensitive media content' (EIGE 2013, 1). The relationship between gender representation in media leadership and media content has been less researched than the number of journalists in the newsroom and the representation and portrayal of women in media content. So far, however, there is little indication that having more women in top positions in media organisations will necessarily lead to greater representation of women in the content they produce. Women, for example, are better represented in top-level positions in public media companies in Nordic countries than in private media companies, but public media organisations do not necessarily have more female subjects in their news content (Andreassen 2015; Övrebø 2015).

\section{Methodology}

The aim of the GMMP is to map the representation and portrayal of women, focusing on a single day of news coverage across the world every five years (GMMP 2010). From the first research conducted in 1995, the GMMP has taken the pulse of selected indicators of gender in the news media, studying women's and men's presence, gender bias and stereotyping in news media content. In 2015, almost 140 countries took part in the study and monitored the news media on Wednesday 25 March. In Iceland, 186 news stories were coded following the methodology provided by GMMP. The number of women and men as news subjects and as journalists were coded for each story, the types of news in which they were found, and the roles they played in the news, along with the stories' topics, scope, space and reference to sex, gender equality and human rights legislation and policy. The aim of data was to capture a detailed picture of the numbers of women and men in the world's news. To get a more complete illustration 
of news content, the quality of coverage was also coded according to whether stories challenged gender stereotypes. The coding schemes were adapted to each media type and, therefore, differ slightly. ${ }^{2}$

The news media analysed were the two national daily newspapers, Fréttabladio and Morgunbladid, and as instructed by the GMMP methodology, 12-14 news stories on the main news pages were coded. In the broadcasting media, the main newscasts were coded: the 12:20 news on RÚV Radio and the 19:00 and 22:00 news on RÚV TV; the 12:00 news on Bylgjan and the 18:30 newscast on Stö 2 (both owned by the private media company, 365 Media). Six online news sites were monitored: dv.is, an affiliate of the bi-weekly DV; mbl.is, an affiliate of Morgunbladid; ruv.is, an affiliate of RÚV; visir.is, an affiliate of 365 Media; and two online-only news sites independent of traditional media, eyjan/pressan.is and kjarninn.is. These sites were the most read general online news sites, according to the Modernus Coordinated Webmeasure (Modernus, n.d.). Ten women — two researchers and eight students in gender studies and in journalism-coded the news on the monitoring day. The authors explained the coding system at the beginning of the coding session, and the group worked together while coding and discussed questions and disagreements to ensure reliability.

\section{Analysis}

On the domestic side, 25 March 2015 was a rather quiet, typical news day not dominated by a single story or topic. The main story of the day was in foreign news, and the crash of the Germanwings airplane in the French Alps featured prominently in all the media. The dismissal of the British Top Gear presenter, Jeremy Clarkson, was also quite prominent, especially on the Internet. Domestic top news stories included labour disputes, layoffs in the Transport Authority Office, structural changes in the Icelandic Developmental Agency and disputes over the location of a new national hospital. Figure 1 shows the proportion of news in Iceland for each of the six main news topic categories used in the GMMP study. The economy was the most prominent topic in both off- and online news; these topic included stories on economic policy, labour issues, housing, consumer issues and transportation. The second biggest topic was the category celebrity, arts, media and sports; the majority of those stories were about sports. As seen in Figure 1, there were only minor differences in coverage between online media and print, radio and television media. 
Figure 1. Main news topics in traditional and online media, 2015 GMMP, Iceland

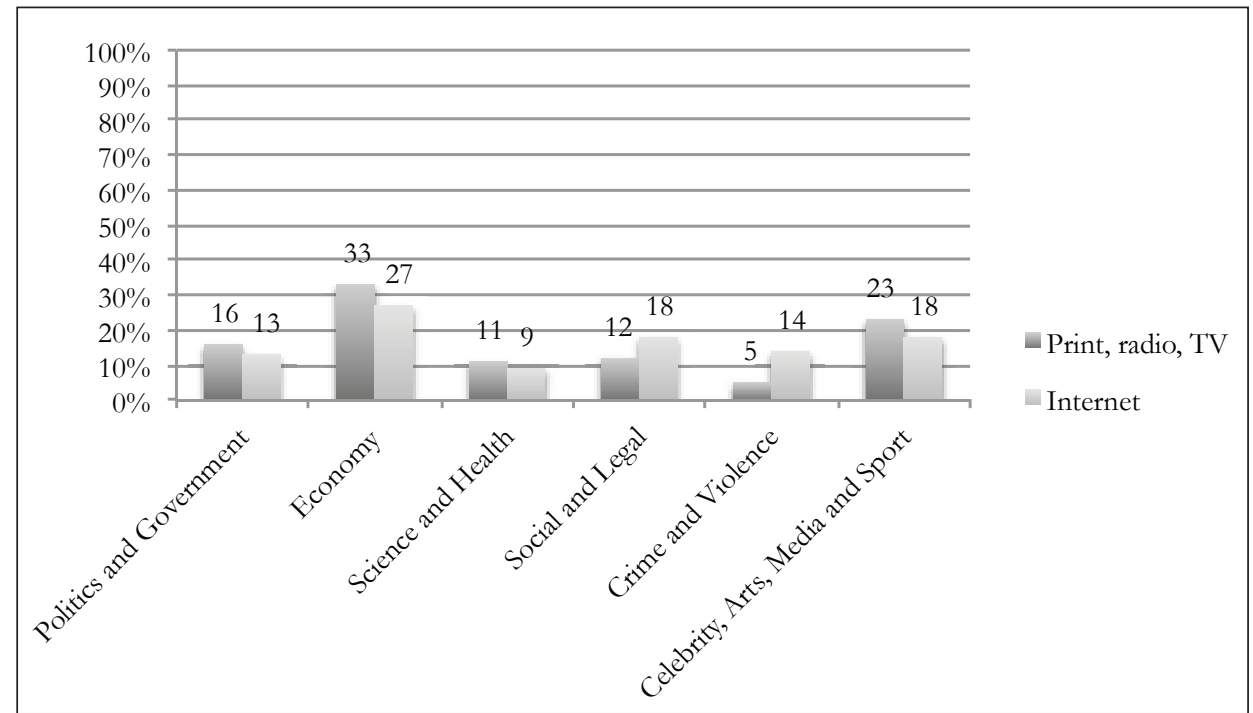

The economy was also the most common topic in the Icelandic results from the 2010 GMMP (Árnadóttir et al. 2010). In Europe, political news generally has been the most common topic, but the interest in economic news in Iceland is unsurprising as the country was still dealing with the aftermath of the financial crisis in 2008. In other Nordic countries, the highest or the second highest proportion of stories occurred in the category of social and legal issues (migration, development, human rights, education, disasters, accidents and public disorder), but otherwise, the Nordic countries differed greatly in the proportion of stories on each topic.

The people in the news are mostly men. In all media in Iceland, only 1 in 5 of those interviewed, spoken of or written about were women. Excluding Internet media which was not included in the 2010 analysis, the proportion of women is $18 \%$, significantly less than the 28\% in the 2010 GMMP (Árnadóttir et al. 2010) and in other Nordic countries, as seen in Figure 2. The results for the Nordic countries in 2015 GMMP in Figure 2 are presented separately for traditional media and the Internet. In Europe, women constituted an average of $26 \%$ of news subjects in print, radio and television and $25 \%$ in Internet news in 2015 (GMMP 2015). Among the 114 countries in the 2015 GMMP study, an average of only $24 \%$ of the people heard, spoken of or written about in print, radio and television news were women, the exact same proportion as five years earlier (GMMP 2015). 
Figure 2. Proportion of female news subjects by medium and Nordic country, 2015 GMMP

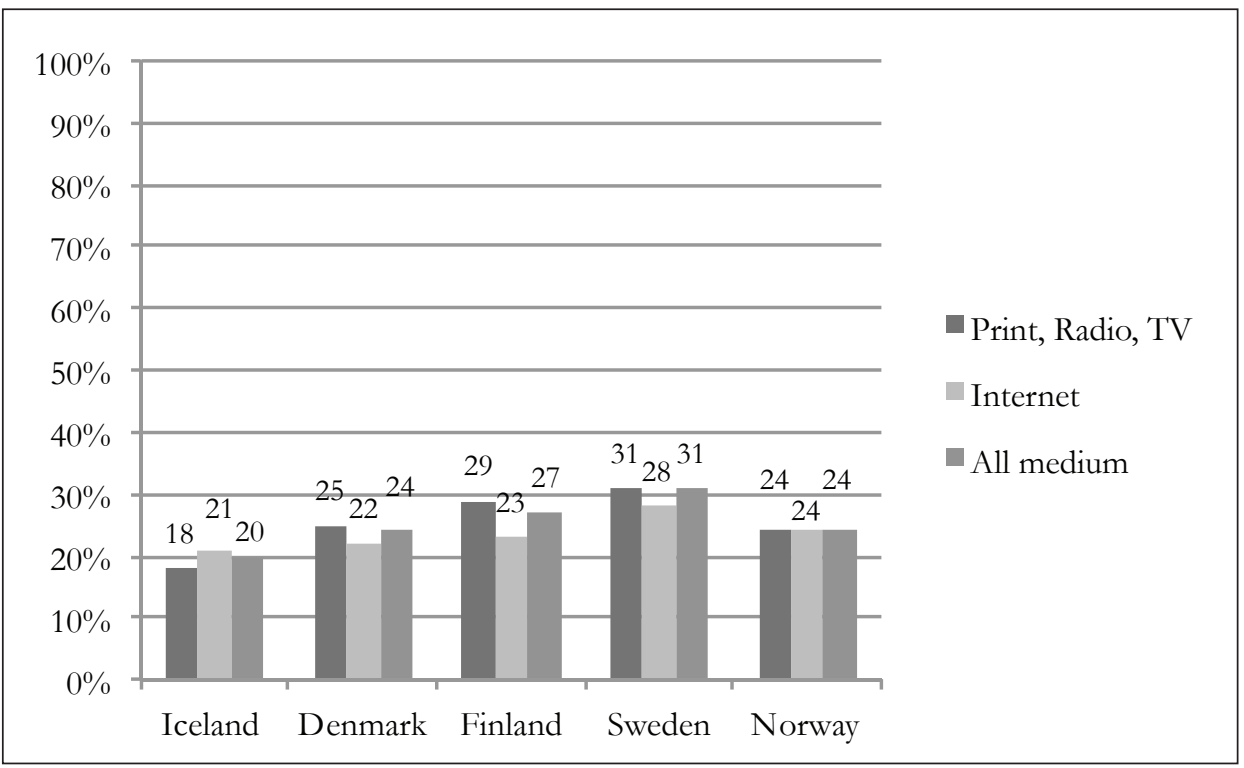

Figure 2 also shows that the relative invisibility of women in traditional news media is replicated in Internet news. Female news subjects are proportionally fewer in Internet stories in Denmark, Sweden and Finland, but proportionally greater in Iceland and Norway.

The proportion of stories with female news subjects is the same or less than in 2010 in the other Nordic countries, as well as in Iceland, as seen in Figure 3. Only in Sweden has the 25\%-30\% pain threshold (Eide 2001, 27) or paper ceiling (Shor et al. 2013, 767) been breached and that by only a small margin. 
Figure 3. Percentage of female news subjects in print, radio and television in 2010 and 2015 GMMP by Nordic country

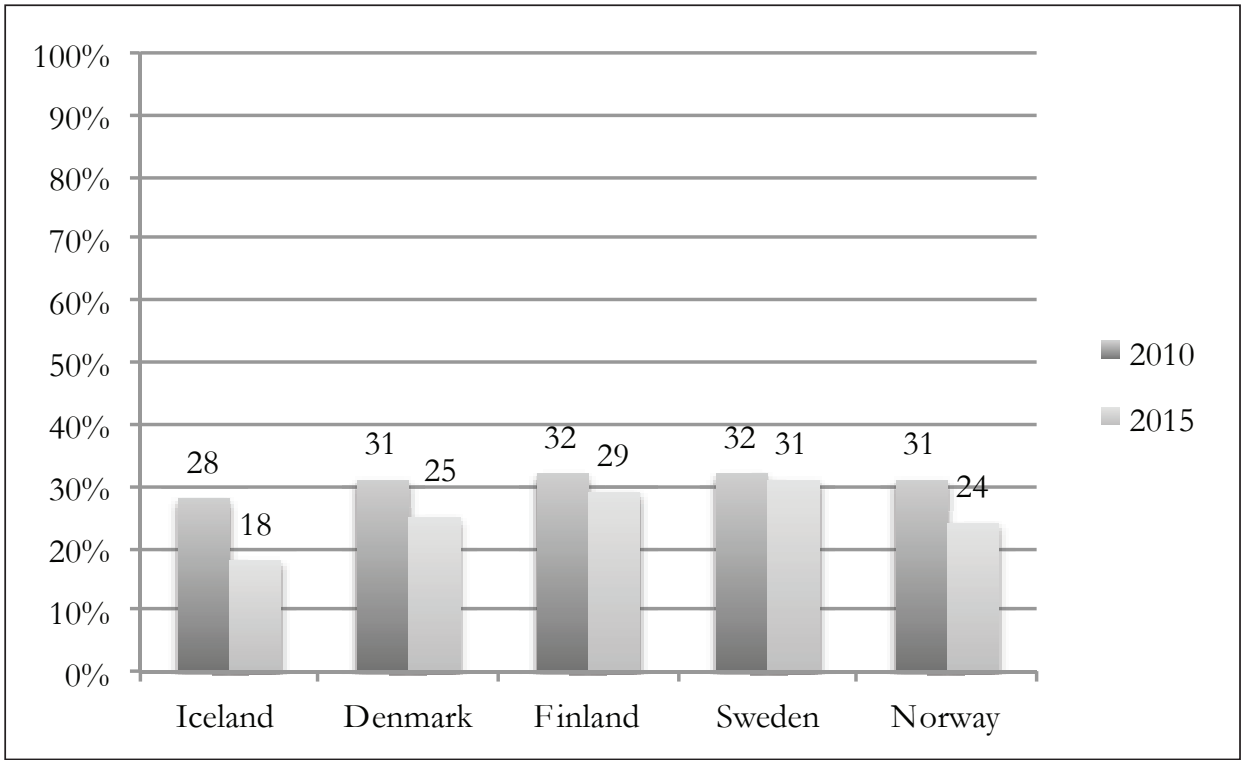

Many studies have shown that women are featured as news subjects much less frequently than men in the so-called hard news about politics, the economy and crime (GMMP 2010). This trend does not seem to have been the case in the Icelandic news media in either 2015 or 2010 (Árnadóttir et al. 2010). Although only 1 in 5 of those interviewed, spoken of or written about are women, and they account for $26 \%$ of subjects in political news. This pattern becomes clear when looking at the proportion of men and women in stories for each main news topic, as seen in Figure 4.

Figure 4. Percentage of stories topics by gender, 2015 GMMP, Iceland

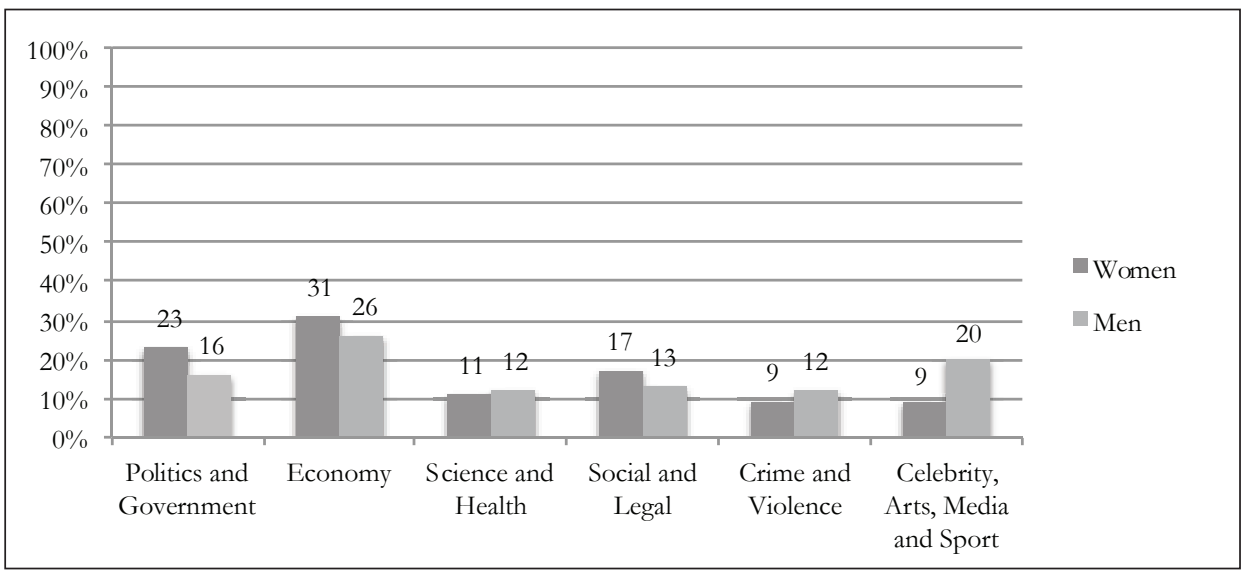




\section{STJÓRNSÝSLA}

Figure 4 shows that, although fewer women are news subjects, the internal pattern within each gender is somewhat different. Among all the stories with women as news subjects, $23 \%$ are about politics, compared to $16 \%$ of news stories with men as subjects. Within their gender, women are more likely than men to appear in news stories about the economy, whereas men are more likely than women to appear in celebrity, arts, media and sports news. These findings are contrary to those in most countries in earlier GMMP studies (GMMP 2010). The latter topic category is very wide, as mentioned, and hides other gender differences. Hence, sports news has been an almost exclusively male domain for a long time (Ólafsson 2006; Daðason 2013). The few celebrity news stories reported on the monitoring day also happened to mostly be about the dismissal of Clarkson, a male television presenter.

It is not just the people in the news who are mostly men but also the people who bring us the news. In Iceland, women reported slightly less than a third of the news stories in 2015 , or $31 \%$, compared to $33 \%$ in 2010 . In Internet news, women's share was lower: 1 in 4 stories. It is important, however, to bear in mind that in close to a third of Internet news stories, the sex of the journalist was not known. As shown in Figure 5 , the situation in Iceland is similar to that in Denmark, but proportionally, women report more news in Norway, Sweden and especially Finland. The change is not monodirectional or significant, expect in Sweden, where women constituted 35\% of those reporting the news, compared to $52 \%$ five years earlier.

Figure 5. Percentage of female journalists in 2010 and 2015 GMMP by Nordic country

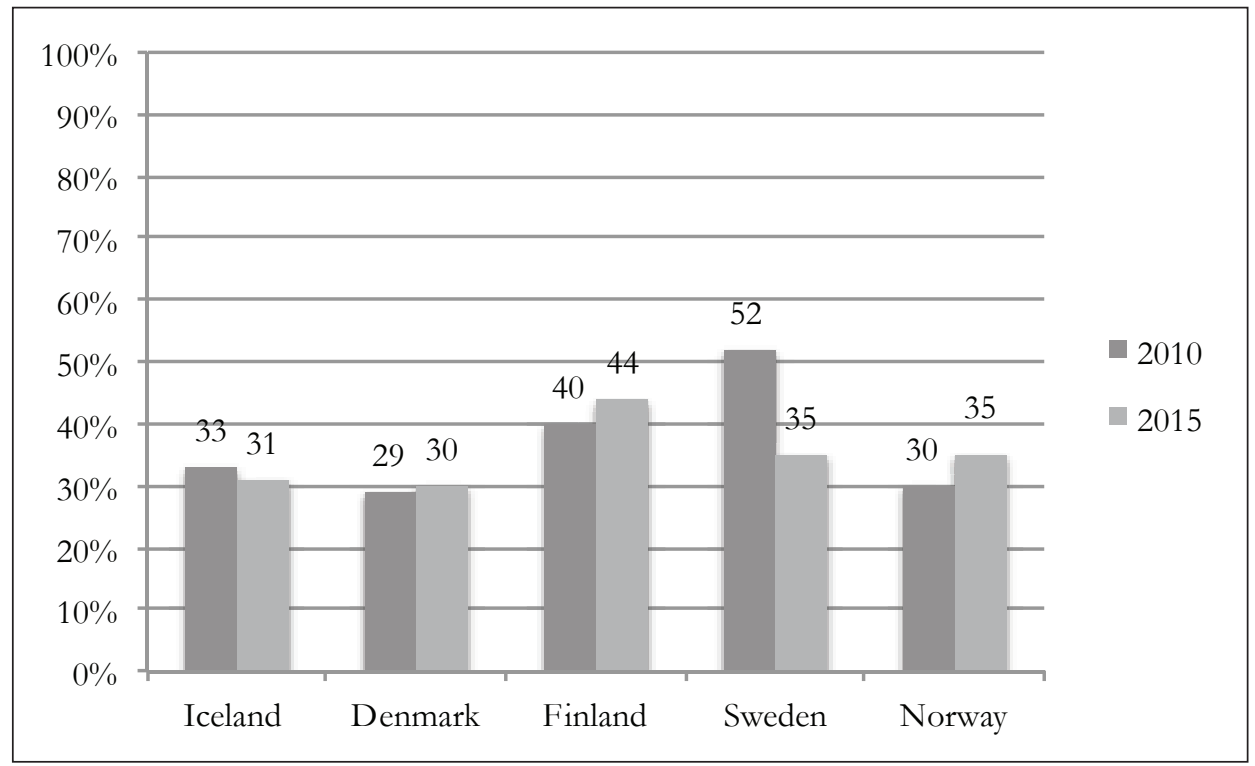


Past GMMP studies have shown that women are less likely to report news about politics, the economy, crime and violence (GMMP 2005; Sarikakis 2013). However, as seen in Figure 7, the findings for Iceland indicate that this pattern was not the case in 2015 or 2010 (Árnadóttir et al. 2010). Although women reported only 31\% of the news overall, they reported $42 \%$ of the political news, a third of social and legal stories and $26 \%$ of economic stories.

Figure 6. Percentage of female journalists by topic, 2015 GMMP, Iceland

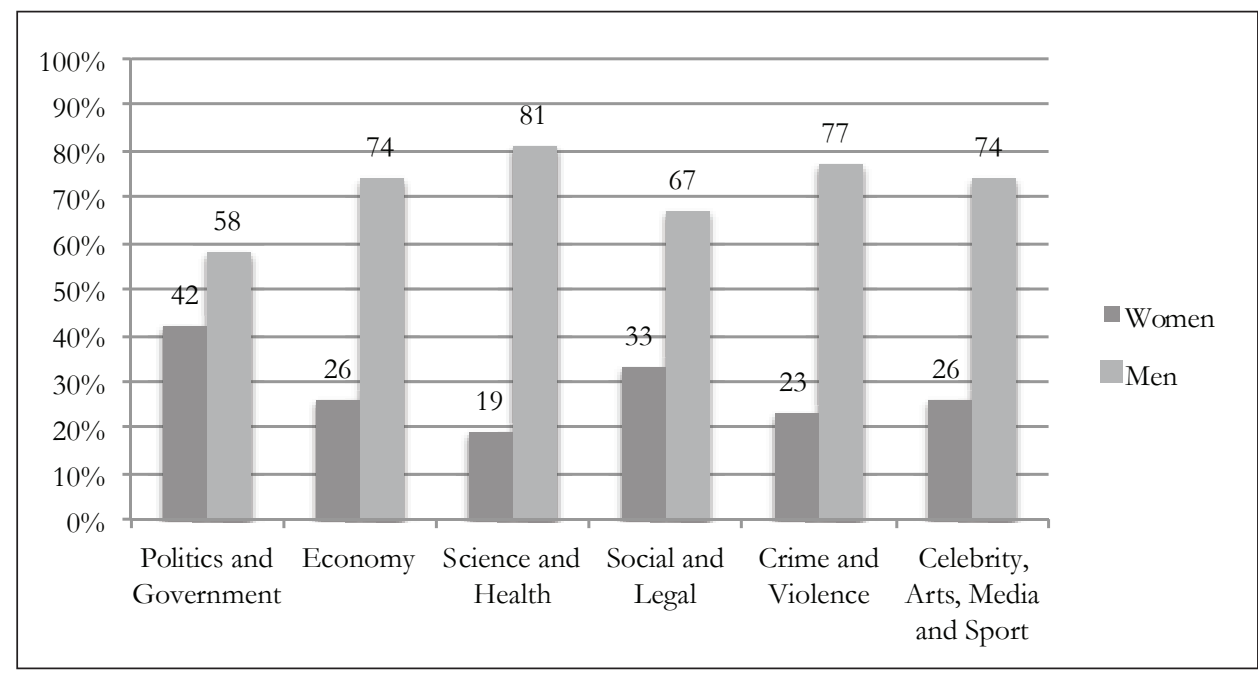

Contrary to the result for Iceland in the 2010 GMMP, female reporters were far more likely than men to feature women news subjects in their stories. The GMMP 2015 findings for Iceland show that women were interviewed, spoken of or written about in one third, $33 \%$, of the stories women reported but only $8 \%$ of those men reported. On average in the 2015 GMMP, 29\% of news stories reported by female journalist had female subjects, compared to $26 \%$ of stories by male reporters (GMMP 2015). In Europe, however, there generally was no difference between women and men journalist in this area. Studies on this point have also been inconclusive, as discussed (GMMP 2010, Árnadóttir et al. 2010, Shor et al. 2013). Some research indicates that women journalists tend to be more receptive of women than men, while others suggest that the number of female journalists does not make the crucial difference. This discrepancy supports the argument that this relationship is complex, and more varied approaches are needed to understand the mechanisms behind it. Finally, women were not only underrepresented in the news that particular day in March 2015 selected for monitoring. It was also clear that gender (in)equality was not on the news agenda. In the GMMP study, a search for stories in the Icelandic news media referring to gender (in)equality or human rights in general found none. 


\section{STJÓRNMÁL \& \\ STJÓRNSÝSLA}

\section{Discussion}

With the Beijing Declarations and the Platform for Action, United Nations member states committed to actively work towards increasing women's participation in and access to expression and decision making in and through the media and promoting a balanced, non-stereotyped portrayal of women in the media (World Conference on Women 1995). It has long been expected that gender balance in media would occur automatically with increased representation of women in decision-making positions in society or that the media industry itself would deal with the problem and take measures to improve gender equality. The relationship between the state or government and the media is delicate, and any influence exerted by the state can easily be interpreted as interference with the media's autonomy and even as an attack on the freedom of expression (Frjáls Fjölmiðlun 2015).

However, different authorities have put forth demands on this issue. Recently, the EU and the European Council have started to put more pressure on member states to take actions to increase gender equality in the media, both within media organisations and in their content. Media companies in the EU are obliged to report on their progress fulfilling the Beijing Action Plan objectives (Edström 2015). In Iceland, as in other Nordic countries, there is political consensus that women and men should enjoy the same rights, obligations and possibilities in society. Icelandic media companies are obliged to comply with demands for gender equality work under the Act on the Equal Status and Equal Rights of Women and Men and to report to the Media Commission on the gender situation. Although this law was passed in 2011, no reports have been published yet (Jóhannsdóttir 2015). The Media Commission has wide-ranging functions and duties (Fjölmiðlanefnd n.d.), but it has been underfinanced and understaffed.

It is often argued that the news media simply reflect societies in which men have considerably more power than women in most areas of life. Elite research in Scandinavian countries, for example, has shown that men hold the majority of powerful positions in most sectors of society (Niskanen 2011). Consequently, although women occupy around $40 \%$ or more seats in national parliaments in the Nordic countries (slightly less in Denmark) (Inter-Parliamentary Union 2015), this reality is not reflected in the media. The same pattern holds true in Iceland where the proportion of in decision-making positions and their participation in public life have been gradually increasing (Statistics Iceland 2015; Rafnsdóttir et al. 2014). Iceland has also been at the top of the overall rankings of the Global Gender Gap Index since 2008 (WEF 2015). However, the representation of women in Icelandic media is still far from accurately reflecting the position of women according to the Global Gender Gap Index. The case of Iceland, therefore, supports the argument that there is not a simple relationship between women's participation in public life or decision-making positions and the number and the representation of women in media.

The GMMP is important from several perspectives. As a longitudinal and global study, it has several potentialities, not the least its ability to show shifts in patterns of inequality over time and across continents (Ross \& Carter 2011). Since the first GMMP 


\section{STJÓRNSÝSLA}

study in 1995, the number of female journalists has risen steadily (Hanitzch 2014), but women's presence in the news has not increased accordingly (GMMP 2010). The explanations that the media reflect society and that the representation of women in news increases with the number of female journalists do not apply. As Ross $(2011,19)$ puts it, 'if what we see and read and hear are men's voices, men's perspective, men's news then women continue to be framed as passive observers rather than active citizens'.

The GMMP, EIGE study (2013) and similar studies focused on gender representations have been criticised for having a narrow perspective. Andreassen (2015), for example, stresses that equal rights and diversity are a question not only of gender but also of race, ethnicity, handicap, class and sexual orientation. Others have pointed out counting heads is not enough and that a more qualitative approach is necessary (Árnadóttir et al. 2010). Djerf-Pierre (2011, 45), however, argues that 'simple counting' actually is neither simple nor atheoretical but a theoretically and empirically challenging endeavour needed to reveal structural horizontal and vertical segregation.

The methodology of the GMMP, focusing on one day's news coverage, is not without its limitations, and there is the risk that the results are skewed in comparison with other days (Andreassen 2015). As stated, the crash of the Germanwings plane in the Alps was the major story in all the news media on the monitored day in 2015, and the aviation industry is a very much a man's industry (Bridges et al. 2014). This might explain the decline in the proportion of female news subjects in other Nordic countries, at least to some extent. It, however, does not change the fact that women are underrepresented in media content in the Icelandic news media, as in the other Nordic countries and Europe in general, and still account for less than a third of those reporting the news. These findings corroborate those of other studies on the coverage of female subjects. Another limitation of the GMMP is that was started only in 1995, so the larger historical trends are not known. GMMP also only studies the news in broadcast media but as we have seen other research indicate that women are underrepresented in current affairs programs in radio and television (Association of Women Business Leaders in Iceland 2013, Erlingsdóttir 2015). The GMMP study also only analysis the first 12-14 stories in the newspapers and the gender representation of both news subjects and journalist may be different in other sections of the papers. It is however the news the editorial office considers most important that is published on the first pages of the newspapers and therefore it reflects the news value of the paper.

Gender equality in the profession of journalism and in top-level positions is a worthwhile goal as there are no indications that women are uninterested in journalism or in advancing to decision-making positions in their careers (Nefnd um konur og fjölmiðla 2001). However, as seen, there is no direct relationship between the number of women journalists in media organisations and the output they produce. The assumption of such a relationship also seems to imply that all women think and work alike and that their approaches and working practices are fundamental different than the ways that their male collages go about their work (Andreassen 2015). 


\section{STJÓRNMÁL \& \\ STJÓRNSÝSLA}

Finnish researchers have pointed out some contradictions revealed in this discussion. They found that, in Finnish newsrooms, gender is said not make a difference, but gender balance is also seen as important (Savolainen \& Zilliacus-Tikkanen 2015). As seen, there is no simple relationship between women's participation in public life or decisionmaking positions or women working in media (as journalists or in top positions) and the number and representation of women in media. This relationship is highly complex and multifaceted. The well-known gendered characteristics of organisations and structures also apply to media organisations (Savolainen \& Zilliacus-Tikkanen 2015). Statistics on the gender ratio in decision-making positions in media organization in Iceland are lacking as well as research on the actual decision making process in the editorial offices which could help explain the news values at work. The Icelandic media market is also very small and research is needed as to how that affects the working conditions of journalist and their product. Research has for example indicated that increased production output has pushed the journalistic routines in the direction of professional sources, or the 'usual suspects' because it is faster and easier to get hold of a them (Willig 2013). There are also indications that proportionally more women journalists than men were laid off or left the profession in the years after the financial crash in 2008 and that women are more likely to leave the profession because of the working hours (Jóhannsdóttir 2015, Pálsdóttir 2014). The findings of the 2015 GMMP show that Iceland still has a long way to go to achieve gender equality in or through the media and that women's overall presence in news has declined since 2010. In 2015 when Icelanders celebrate the centennial of women gaining voting rights, there is little cause to celebrate the gender situation in the media. More research and monitoring are needed, however, to see whether this decline is temporary and to shed further light on the complex mechanisms discussed.

This research is part of the Icelandic Power and Democracy Research Project (2014-2017). For further information on the research project see: wmw.vol.hi.is

\section{Notes}

1 Iceland participated in data collection in 1995 and 2000, although the data from Iceland were not further elaborated. The data in the 2010 GMMP were collected in 2009 but published in 2010.

2 Detailed information, monitoring guides and coding sheets can be found at http://whomakesthenews.org/media-monitoring/methodology-guides-and-coding-tools.

\section{References}

Allan, S., Branston, G., and Carter C. (eds.) (1988/2014). News, Gender and Power (2nd edition). New York: Routledge.

Andreassen, R. (2015). "Køn i danske medieinstitutioner og danske tv-medier". Nordicom Information $37(2), 5-17$.

Árnadóttir, E., Jóhannsdóttir, V., and Einarsdóttir, P. (2010). "Konur og karlar í fjölmiðlum: Ísland í alpjóðlegri fjölmiðlavöktun”. Bjóðarspegillinn 2010. Rannsóknir i Félagsvísindum XI, pp. 35-45. Retrieved 1 September 2015, from http://reports.weforum.org/global-gender-gap-report-2014/rankings/. 


\section{STJÓRNSÝSLA}

Association of Women Business Leaders in Iceland [Félag kvenna í atvinnulífinu] (2013). Male Interviewees Three Times the Number of Female Interviewees in News [press release]. Retrieved 9 September 2015, from http://www.fka.is/um/frettir/nr/138.

Baitinger, Gail (2015). "Meet the press or meet the men? Examining women's presence in American news media". Political Research Quarterly 2015 68(3), 579-592.

Bridges, D., Neal-Smith, J., and Mills, A.J. (eds.) (2014). Absent Aviators. Gender Issues in Aviation. Surrey, Burlington: Ashgate.

Byerly, C. (2011). Global Report on the Status of Women in the News Media. Washington, DC: International Women's Media Foundation.

Daðason, K.T. (2013). Ípróttafréttamennska á Íslandi: Ípróttaumfjöllun um karla og konur á íslenskum vefmiðlum. Unpublished MA thesis. Reykjavík: University of Iceland.

Djerf-Pierre, M. (2011). “The difference engine”. Feminist Media Studies 11(1), 43-51. doi:10.1080/1468 0777.2011.537026.

Edström, M. (2015). "Svensk journalistik. Bromskloss eller pådrivare for jämställdhet? ” Nordicom Information 37(2), 61-62.

Edström, M. and Mølster, R. (eds.) (2014). Making Change: Nordic Examples of Working Towards Gender Equality in the Media (Vol. 11). Gothenburg: Nordicom.

Eide, E. (2001). "The twenty percent limit for women in news media". NIKK Magasin nr. 3, 2001, 26-29. NIKK, Nordic Institute for Women Studies and Gender.

EIGE, European Institute for Gender Equality (2013). Review of the Implementation of the Beijing Platform for Action in the EU Member States. Advancing Gender Equality in Decision-Making in Media Organisations: Report. Luxembourg: Publications Office of the European Union. Retrieved 9 September 2015, from: http://eige.europa.eu/rdc/eige-publications/advancing-gender-equality-decision-makingmedia-organisations-report.

Einarsdóttir, P., and Hjartardóttir, G.L. (2009). “Kynjaskekkja í stjórnmálum. Breytingar og áhrifapættir". Stjórnmál og stjórnsýsla 5(1), 5-26.

Erlingsdóttir, R.G. (2015). "Viðmælendur í fréttum og völdum umræðupáttum”. Jafnréttisping, 25 November 2015.

Fjölmiðlanefnd (n.d.). Um Fjölmiðanefnd [ About the Media Commission]. Retrieved 9 September 2015, from: http:// fjolmidlanefnd.is/um-fjolmidlanefnd/

Global Media Monitoring Project (1995). Who makes the News? Global Media Monitoring Project 1995, National Watch on Images of Women in the Media (Media Watch) Inc. Retrieved 9 September 2015, from http://cdn.agilitycms.com/who-makes-the-news/Imported/images/reports_1995/gmmp_1995. pdf

Global Media Monitoring Project (2000). Who Makes the News? Global Media Monitoring Project 2000. World Association for Christian Communication. Retrieved 30 October 2105 from http://cdn. agilitycms.com/who-makes-the-news/Imported/reports_2000/gmmp_2000.pdf

Global Media Monitoring Project (2005). Who Makes the News? Global Media Monitoring Project 2005. World Association for Christian Communication. Retrieved 30 October 2015, from http://whomakesthenews.org/gmmp-2015.

Global Media Monitoring Project (2010). Who Makes the News? Global Media Monitoring Project 2010. World Association for Christian Communication. Retrieved 30 October 2015, from http://whomakesthenews.org/gmmp/gmmp-reports/gmmp-2010-reports

Global Media Monitoring Project (2015). Who Makes the News? Global Media Monitoring Project 2015. World Association for Christian Communication. Retrieved 25 November 2015, from http:// whomakesthenews.org/gmmp/gmmp-reports/gmmp-2015-reports

Guðmundsson, B. (2009a). "The Icelandic journalism education”, in Georgios Terzis (ed.), European Journalism Education (pp. 149-159). Chicago: The University of Chicago Press.

Guðmundsson, B. (2009b). Fordómar fjölmiðlafólks? Lecture. Ráðstefna um Íslenska Djóðfélagsfræði, Akureyri, May 2009. 


\section{STJÓRNMÁL \& STJÓRNSÝSLA}

Guðmundsson, B., and Jóhannsdóttir, V. (2013). "Viðhorf og væntingar blaðamennskunema til blaðamennsku”. bjóðarspegillinn 2013. Rannsóknir i félagsvísindum XIV.

Guðmundsson, F.P., Jóhannsdóttir, V., Ólafsson, K., and Broddason, P. (2010). "Umfjöllun fjölmiðla á Íslandi um banka og fjármálafyrirtæki 2006-2008”, in Páll Hreinsson et al. (eds.), Aðdragandi og orsakir falls islensku bankanna 2008 og tengdir atburdir, Páll Hreinsson et al. (eds). Reykjavík: Rannsóknarnefnd Alpingis.

Hanitzsch, T. and Hanusch, F. (2012). "Does gender determine journalists' professional views? A reassessment based on cross-national evidence", European Journal of Communicatio, 27(3), 257-277.

Hálfdánardóttir, A. (2014) Adgengi eða áhugi? Munur á efnistökum og vagi frétta eftir karla og konur. Unpublished MA thesis. Reykjavík: University of Iceland.

Hermano, T., and del Nevo, M. (2000). "Introduction", in Who Makes the News? Global Media Monitoring Project (2000). Retrieved 9 September 2015 from http://cdn.agilitycms.com/who-makes-thenews/Imported/reports_2000/gmmp_2000.pdf

Hovden, J.F., Bjørnsen, G., Ottosen, R., Willig, I., and Zilliakus-Tikkanen, H. (2009). “The Nordic journalists of tomorrow. An exploration of first year journalism students in Denmark, Finland, Norway and Sweden", Nordicom Review 30(1), 149-165.

Inter-Parliamentary Union (2015). Women in National Parliaments. Retrieved 15 October 2015 from http://www.ipu.org/wmn-e/classif.htm.

Jakobsdóttir, E.M. (2005). Karlar og konur i sjónvarpspáttum: Atbugun á birtingu kynjanna í sjónvarpspáttum á RÚV, Stöð 2 og Skjá einum. Reykjavík: Menntamálaráðuneytið. Retrieved 9 September 2010 from http://rafhladan.is/handle/10802/6121.

Jóhannsdóttir, V. 2015. "Women in Journalism: The Situation in Iceland”, Nordicom Information 37 (2), $33-40$.

Jóhannsdóttir, V. and Karlsson, R. (2013). Television News in Competition: A Comparison of the Main Newscast of the Public Broadcasting Company, Rúv, and the Commercial Channel 2. Paper presented at The Icelandic Society 2013, Bifröst.

Kolbeins, G.H. (2012). “Siðferði og starfshættir íslenskra blaða- og fréttamanna”. Djóðarspegillinn 2012. Rannsóknir i félagsvísindum XIII.

Law on Equal Status and Equal Rights of Women and Men no. 10/2008.

Law on the Media no. 38, 2011.

Leiknisdóttir, A.M. (2005). Konur og karlar í auglýsingum: Atbugun á pætti karla og kvenna í auglýsingum á RÚV, Stöð 2 og Skjá einum. Reykjavík: Menntamálaráðuneytið. Retrieved 9 September 2015 from http://rafhladan.is/handle/10802/6124.

Modernus.is (n.d.). Samræmd vefmæling (Coordinated webmeasure). Internet á Islandi. Retrieved 30 October 2015 from: http://veflistinn.is/.

Nefnd um konur og fjölmiðla. (2001). Álit og tillögur. Reykjavík: Menntamálaráðuneytið. Retrieved 30 October 2015 from http://brunnur.stir.is/mrn/utgafuskra/utgafa.nsf/RSSPage.xsp?documentId= 4F2E3C5F41814C0E002576F00058D559\&action=openDocument

Niskanen, K. (ed.).(2010). Gender and Power in the Nordic Countries_With a Focus on Politics and Business. Gothenburg: NIKK Publications, Nordic Institute for Women Studies and Gender.

Olgeirsson, B. (2014, 18 March). “Öllum framkvæmdastjórum RÚV verður sagt upp”, $D V$. Retrieved 30 October 2015 from http://www.dv.is/frettir/2014/3/18/ollum-framkvaemdastjorum-ruv-verdursagt-upp/.

Ólafsson, K. (ed.) (2006). Sports, Media and Stereotypes. Men and Women in Sports and Media. Akureyri: Jafnréttisstofa.

Pálsdóttir. E.S. (2014). Af bverju hattir fólk. i blaða- og fréttamennsku? Um starfið, sögu og breytingar. Unpublished MA thesis. Reykjavík: University of Iceland.

Rafnsdóttir, G.L., Einarsdóttir, D., and Snorrason, J.S. (2014). "Gender quota on the boards of corporations in", in Marc de Vos and Phillippe Culliford (eds.), Gender Quotas on Company Boards (pp. 147156). Cambridge: Intersentia. 


\section{STJÓRNSÝSLA}

Ross, K. (2011) "Silent witness: news sources, the local press and the disappeared woman" in Krijnen T, Alvares C and Van Bauwel S (eds.) Gendered Transformations, 9-24. Bristol: Intellect.

Ross, K. (2014) "Women in decision-making structures in media", in A.V. Montiel (ed.), Media and Gender: A Scholarly Agenda for the Global Alliance on Media and Gender. UNESCO, International Association for Media and Communication Research. Retrieved 30 October 2015 from http://homepage. univie.ac.at/katharine.sarikakis/wp-content/uploads/2011/12/IAMCR.pdf.

Ross, K. (2014). "Women in media industries in Europe: what's wrong with this picture?" Feminist Media Studies, 14(2), 326-330.

Ross, K., \& Carter, C. (2011). "Women and news: A long and winding road". Media, Culture \& Society, 33(8), 1148-1165. doi:10.1177/0163443711418272.

Sarikakis K. (2013). "Power, patriarchy, profit: Barriers to gender mainstreaming in media policy" in in A.V. Montiel (ed.), Media and Gender: A Scholarly Agenda for the Global Alliance on Media and Gender. UNESCO, International Association for Media and Communication Research. Retrieved 30 October 2015 from http://homepage.univie.ac.at/katharine.sarikakis/wp-content/uploads/2011/12/ IAMCR.pdf

Savolainen T., and Zilliacus-Tikkanen, H. (2015). "The gender division and hierarchies of the Finnish news organisations”, Nordicom Information 37(2), 19-31.

Shor, E., van de Rijt, A., Ward, C., Blank-Gomel, A., \& Skiena, S. (2013). "Time trends in printed news coverage of female subjects, 1880-2008”, Journalism Studies 15(6), 759-773.

Statistics Iceland (2009). "Women and men in positions of influence 2008", Statistical Series 2009, 1. Retrieved 30 November 2015 from https://www.hagstofa.is/media/43483/hag_090123.pdf.

Statistics Iceland (2015). Konur aldrei fleiri i hópi blada- og fréttamanna. April 16 2015. Retrieved 30 October 2015 from http://www.hagstofa.is/utgafur/frettasafn/midlun/blada-og-frettamenn-2014/.

Stefánsdóttir, S. (1988). "Ekkert er helst að frétta af konum í atvinnulífinu". 19. júní38 (1), 66-68.

Stefánsdóttir, S. (2013). Bág staða islenskra blaðakvenna: Greining á Fréttabladinu, Morgunbladinu og DV. Unpublished MA thesis. Reykjavík, University of Iceland.

Steiner, L. (2012). "Failed theories: explaining gender difference in journalism". Review of Communication, 12(3), 201-223.

Tuchman, G. (1979). "Women’s depiction by the mass media", Signs, 4(3), 528-542.

Valdimarsdóttir, M. (2005). Karlar og konur í íslensku sjónvarpi. Fréttir. Reykjavík: Menntamálaráðuneytið. Retrieved 9 September 2015 from http://rafhladan.is/handle/10802/6122.

Van Zoonen, L. (1998). "A professional, unreliable, heroic marionette (M/F: Structure, agency and subjectivity in contemporary journalisms", European Journal of Cultural Studies, 1(1), 123-143. doi:10.1177/136754949800100108.

Viðskiptablaðið (2014, 25 August). Forstjóri 365 vill auka blut kevenna i fréttaskrifum. Vidskiptabladid. Retrieved 15 September 2014 from http://www.vb.is/frettir/108677/.

White, A. (2009). Getting the Balance Right: Gender Equality in Journalism. Brussels: International Federation of Journalists. Retrieved 30 October 2015 from http://www.unesco.org/new/en/communicationand-information/resources/publications-and-communication-materials/publications/ full-list/ getting-the-balance-right-gender-equality-in-journalism/

Whitt-Barthel, A. (2006) EFJ Survey: Women Journalists in the European Integration Process. Retrieved 30 October 2015 from http://www.ifj.org/fileadmin/images/Gender/Gender_documents/EFJ_Survey_Women_Journalists_in_the_European_Integration_Process_2006.pdf

Willig, Ida. 2013. "Le pluralisme des médias au Danemark : presse écrite et en ligne”, in F. Rebillard \& Loicq, M. (eds.), Pluralisme de l'information et media diversity, (pp. 149-169). Berchem: De Boeck.

World Economic Forum (2014). The Global Gender Gap Index 2014. Retrieved 30 October 2015 from http://reports.weforum.org/global-gender-gap-report-2014/part-1/

World Conference on Women (1995). The Beijing Declaration and Platform for Action. New York: Department of Public Information, United Nations. Retrieved 30 October 2015 from http://beijing20. unwomen.org/ /media/headquarters/attachments/sections/csw/pfa_e_final_web.pdf. 
Dórisdóttir, A.L. (2010). Dádleysi kvenna. Eða er öðru um að kenna? Stjórnmálakonur i fjölmiðlum fyrir Alpingiskosningarnar 2009. Unpublished MA thesis. Unpublished MA thesis. Reykjavík: University of Iceland.

Øvrebø, T. (2013). "Norway: the uncomfortable gender gap in news media", in C.M. Byerly (ed.), The Palgrave International Handbook of Women and Journalism, (pp. 137-150). Basingstoke: Palgrave Macmillan.

Øvrebø, T. (2015). "Verdien av en kvinnes stemme. Om kjønn. makt og endring i norsk nyhetsproduksjon", Nordicom Information, 37(2), 41-55. 
